\title{
The Human Testis
}




\section{ADVANCES IN EXPERIMENTAL MEDICINE AND BIOLOGY}

Editorial Board:

\section{Nathan Back}

N. R. Di Luzio

Alfred Gellhorn

Bernard Halpern

Ephraim Katchalski

David Kritchevsky

Abel Lajtha

Rodolfo Paoletti
Chairman, Department of Biochemical Pharmacology, School of Pharmacy, State University of New York, Buffalo, New York

Chairman, Department of Physiology,

Tulane University School of Medicine, New Orleans, Louisiana

University of Pennsylvania Medical School, Philadelphia, Pennsylvania

Collège de France,

Director of the Institute of Immuno-Biology, Paris, France

Department of Biophysics, The Weizmann Institute of Science, Rehovoth, Israel

Wistar Institute, Philadelphia, Pennsylvania

New York State Research Institute for Neurochemistry and Drug Addiction, Ward's Island, New York

Institute of Pharmacology, University of Milan, Milan, Italy
Volume 1

THE RETICULOENDOTHELIAL SYSTEM

AND ATHEROSCLEROSIS

Edited by N. R. Di Luzio

and R. Paoletti 1967

Volume 2

PHARMACOLOGY OF HORMONAL

POLYPEPTIDES AND PROTEINS

Edited by N. Back, L. Martini,

and R. Paoletti $\cdot 1968$

Volume 3

GERM-FREE BIOLOGY-Experimental

and Clinical Aspects

Edited by E. A. Mirand and N. Back $\bullet 1969$

Volume 4

DRUGS AFFECTING LIPID METABOLISM

Edited by W. L. Holmes, L. A. Carlson,

and R. Paoletti $\cdot 1969$

Volume 5

LYMPHATIC TISSUE AND GERMINAL

CENTERS IN IMMUNE RESPONSE

Edited by L. Fiore-Donati

and M. G. Hanna, Jr. $\bullet 1969$

Volume 6

RED CELL METABOLISM AND FUNCTION

Edited by George J. Brewer • 1970

Volume 7

SURFACE CHEMISTRY OF

BIOLOGICAL SYSTEMS

Edited by Martin Blank • 1970
Volume 8

BRADYKININ AND RELATED KININS :

Cardiovascular, Biochemical, and Neural Actions

Edited by F. Sicuteri, M. Rocha e Silva, and N. Back $\bullet 1970$

Volume 9

SHOCK: Biochemical, Pharmacological, and Clinical Aspects

Edited by A. Bertelli and N. Back $\bullet 1970$

Volume 10

THE HUMAN TESTIS

Edited by E. Rosemberg

and C. A. Paulsen • 1970

Volume 11

MUSCLE METABOLISM DURING EXERCISE

Edited by B. Pernow and B. Saltin $\cdot 1971$

Volume 12

MORPHOLOGICAL AND FUNCTIONAL ASPECTS OF IMMUNITY

Edited by K. Lindahl-Kiessling, G. Alm, and

M. G. Hanna, Jr. • 1971

Volume 13

CHEMISTRY AND BRAIN DEVELOPMENT

Edited by R. Paoletti and A. N. Davison • 1971

Volume 14

MEMBRANE-BOUND ENZYMES

Edited by G. Porcellati and F. di Jeso $\bullet 1971$ 


\section{The Human Testis}

Proceedings of the Workshop Conference held at

Positano, Italy, April 23-25, 1970

Edited by

Eugenia Rosemberg, M. D.

Research Director, Medical Research Institute of Worcester, Inc.

Worcester City Hospital

Worcester, Massachusetts

and

C. Alvin Paulsen, M. D.

Professor of Medicine

University of Washington School of Medicine

Seattle, Washington

\section{A SERONO FOUNDATION SYMPOSIUM}

P PLENUM PRESS • NEW YORK-LONDON • 1970 
ISBN-13: 978-1-4615-9010-1

e-ISBN-13: 978-1-4615-9008-8

DOI: $10.1007 / 978-1-4615-9008-8$

First Printing - September 1970

Second Printing-March 1971

Library of Congress Catalog Card Number 70-129058

SBN 306-39010-8

๑ 1970 Plenum Press, New York

Softcover reprint of the hardcover 1st edition 1970

A Division of Plenum Publishing Corporation

227 West 17th Street, New York, N.Y. 10011

United Kingdom edition published by Plenum Press, London

A Division of Plenum Publishing Company, Ltd.

Donington House, 30 Norfolk Street, London W.C.2, England

All rights reserved

No part of this publication may be reproduced in any form without written permission from the publisher 
PREFACE

This volume describes the proceedings of the Workshop Conference on The Human Testis which was held at Positano, Italy, April 23-25, 1970 .

The format of the book has been arranged according to topics discussed during the Conference. Each chapter includes individual contributions followed by discussion. Thus, this volume provides a current critical evaluation of the subjects discussed. The Editors assume responsibility for any shortcomings and wish to thank all participants for their unprecedented cooperation in making this publication possible.

The Editors are indebted to Miss Barbara Martin for her able secretarial and administrative assistance and to Mrs. Griff T. Ross who supervised the secretarial staff during the conference. Recognition is also due to Mrs. M. Flack for editorial assistance.

The Workshop Conference could not have taken place but for the Serono Foundation, which supported this Meeting as well as the publication of the Proceedings of this Workshop. The physical as well as the technical arrangements were under the careful direction of Mr. Cesare Florimonte of the Serono Foundation. The support provided by the Serono Foundation is another proof of its generosity in stimulating scientific exchanges and a demonstration of its continuous efforts to support basic and applied studies in the field of human reproduction.

We express our thanks to our Publisher, Plenum Press, for their fine cooperation and for ensuring the rapid publication of this volume.

May, 1970

Eugenia Rosemberg

C. Alvin Paulsen 


\section{ACKNOWLEDGMENTS}

Individual participants wish to thank Editors and Publishers of journals and books for permission to reproduce previously published figures and tables.

Individual participants desire to express their gratitude to the Endocrine Study Section, National Institutes of Health, USPHS, Bethesda, Maryland, U.S.A., to the National Pituitary Agency, Baltimore, Maryland, U.S.A.; to the Department of Biological Standards, National Institute for Medical Research, Mill Hill, London, and to the Istituto Farmacologico Serono, Rome, Italy, for generous supplies of hormones.

Grants supporting work presented in these proceedings are acknowledged by individual participants and indicated in their respective contributions. 
FOREWORD

During the past twenty years many meetings concerning the reproductive process have taken place. Both structure and function of female and male gonads have been major topics at these gatherings. However, in only a few instances has the male gonad, particularly the human, been the main subject of discussion. This Conference was designed to focus attention on the human testis. A group of investigators representing various scientific disciplines was invited to this Workshop to discuss this subject from a morphologic,physiologic, biochemical, genetic and pathologic point of view. In some areas, especially that related to embryology, basic human data are lacking, thus relevant animal studies were also presented。 Effort was made in these comparative studies to illuminate rather than complicate the understanding of fundamental phenomena in human reproductive physiology.

This volume contains the Proceedings of this Workshop which served as a forum for interexchange of ideas which have enriched our know1edge of the human testis. If the topics discussed excited our interest for further research and have opened new and original lines of study, then the organization of this gathering was amply justified.

\author{
Roberto E. Mancini, M. D. \\ May, 1970
}




\title{
INTRODUCTORY REMARKS
}

\author{
Roberto E. Mancini, M. D.
}

Since its creation, mankind has been concerned with problems related to reproduction. Most of the ancient religions clearly exhorted the people to multiply, as this was considered the main if not the only object of marriage. Although this preoccupation seemed from the beginning to involve both the female and male aspects of the pair, a preferential and unbroken thread of attention was paid to the knowledge of the ovary and female genital tract. From the earliest writers to modern researchers, this interest in the female sexual function has also been reflected in the continuous recommendation to seek a reliable method for the control of fertility applicable only to women. In consequence a considerable amount of data has been accumulated on the biology of the ovary as compared with the smaller quantity on the testis. However, the importance and significant symbolism of the untouchable male gonad appeared reinforeed in the ancient Assyrian times, when a woman or even a physician who consciously or unconsciously caused an injury to the testis of a man, could be punished by having their hands cut off. Yet, the shadows of this rather superstitious concept has persisted until today, where in some countries, it is more difficult to get a biopsy of the testis than to perform a similar one on the endometrium or even on the ovary.

It was not before the decade following 1940 that our cognizance of the human testis, thanks to the introduction of surgical biopsies, became a reality and so the mysterious aura which had surrounded the male gonad began to vanish. The biopsy was rapidly incorporated by endocrinologists and urologists as a diagnostic tool. A few years later, studies on the normal and abnormal histology of the different structures of the testis corroborated and amplified previous necropsy findings, and the pathological background of more than one endocrine or non-endocrine disease of this gland was established. A pioneer group of well-known North American, European and Latin American authors have greatly contributed to the opening of this new field of investigation. To all of them, dead or alive, we convey on this 
special occasion our feelings of sympathy and admiration. Since then, the development of laboratory research and biochemical techniques has led to further progress in important areas of testicular biology. Thus incontestable histophysiological evidence of some basic mechanism operating in the male gonad has been elucidated. This is with special reference to the cellular and subcellular morphology of germinal epithelium and interstitial Leydig cells, and to the final products of both structures, sperm cells and male hormones and the feedback phenomena with the hypophysis.

Apart from the advanced studies on the relationship between Leydig cells and steroidogenesis, we are just at the beginning of our understanding of: a) the dynamics of the human spermatogenic process which is replacing the old wavecycle concept of classical cytologists; b) the sustentacular and nutritional function of Sertoli cells related to germinal cells and spermatozoa; c) the functional significance of the physico-chemical composition of seminiferous tubular wall structures; d) the development and fate of sex chromosomes in the germinal cells; e) some histochemical aspects of spermatogenesis; f) the effects of follicle stimulating and luteinizing hormones and some steroids on the development of germinal and Sertoli cells and interstitial tissue.

Unfortunately, an extension of these approaches is restricted by the small quantity of tissue present in biopsies. However, it is eagerly hoped that more refined instrumentation and methodology will prove rewarding in a more profound analysis of human testicular structure and function, as has occurred with the animal testis. Tissue organ culture techniques, which permit an observation of the direct effect of different agents, molecular biological aspects of cell populations, the metabolic pathway of germinal and Sertoli cell function, the role of tubular wall structures and Sertoli cells in the intratubular diffusion of different molecules, the relationship between Leydig cell steroids and germinal epithelium, cellular and subcellular receptors for the gonadotropic hormones, hypothalamus-hypophysealtesticular interrelation, radioimmunoassays for $\mathrm{FSH}$ and $\mathrm{LH}$, and hemodynamic aspects of testicular function are some of the topics which urgently need the attention of investigators.

This is precisely what this Workshop Conference is intended to do. It is not an exhaustive review of what is known today about the physiology and pathology of the human testis, but is to add a new dimension to our knowledge of this gland by outlining new evidence and provoking additional thoughts and inspiration for further studies. This is the reason why other pathological disorders of the testis, such as inflammation, congenital abnormalities, infections and tumors have been deliberately excluded. On the other hand some other recent approaches which are beginning to contribute to the elucidation of disturbances in the mechanism of spermatogenesis have been added, 
i.e., immunological factors, chromosomal anomalies of germinal cells, and other topics concerning the significance of seminal plasma chemical composition as an indicator of the adnexal gland function. It was also fully realized that the introduction of a subject related to the assessment of gonadotropin therapy in the still debatable field of male sterility, should be at present of paramount importance. This appears more than justified when it is considered that almost half of infertility in couples is due to the male factor.

It is our intention that all these topics will form a solid guide for present and future fundamental studies, which in turn will provide a better understanding of why and how testicular structure and function may become abnormal. Needless to say the benefit of this view will lead to a rational approach in the study of the heterogenous group of sterile patients, or what today is considered equally important, as a counterpart, to new tools for male contraception.

Finally, the aim of this Workshop Conference was not only to have the pleasure of meeting experts on a subject of common interest, but also to demonstrate that the integrated efforts of embryologists, biologists, geneticists, biochemists, pathologists and endocrinologists will be of great help in substantially increasing the information at present available on the physiology and pathology of the human testis. 
LIST OF PARTICIPANTS

Cesar Bergada, M. D.

Director of Research

Department of Endocrinology

Hospital de Ninos

Gallo 1330

Buenos Aires, Argentina

Professor Mario Hector Burgos, M. D.

Instituto de Histologia y Embriologia

Facultad de Ciencias Medicas

Universidad Nacional de Cuyo

Casilla de Correo 56

Mendoza, Argentina

Ann C. Chandley, Ph. D.

Research Scientist

Medical Research Council

Clinical and Population Cytogenetics Research Unit

Western General Hospital

Crewe Road

Edinburgh 4, Scotland

A. Kent Christensen, $\mathrm{Ph}$. D.

Associate Professor of Anatomy

Stanford University

Department of Anatomy

Stanford School of Medicine

Stanford, California 94305

Professor Yves Clermont, Ph. D.

Department of Anatomy

McGil1 University

Strathcona Medical Building

3640 University Street

Montreal 112, Quebec, Canada 
Michel Courot

Maitre de Recherches

Institut National de 1 a Recherche Agronomique

Lab. Physiologie de la Reproduction

37 Nouzilly - France

Joseph R. Davis, M. D., Ph. D.

Professor of Pharmacology

Loyola University Stritch School of Medicine

2160 South First Avenue

Maywood, Illinois 60153

Professor Egon R. Diczfalusy, M. D。

Director, Reproductive Endocrinology Research Unit

Swedish Medical Research Council

Karolinska Sjukhuset

Stockholm 60, Sweden

Piero Donini, M. D.

Director of Research Laboratories

Istituto Farmacologico Serono

Via Casilina 125

Rome, Italy

C. E. Ford, D. Sc., F.R.S.

Head, Cytogenetics Group

Medical Research Council Radiobiology Unit

Harwe11, Didcott

Berkshire, United Kingdom

Irving I. Geschwind, Ph. D.

Professor of Animal Science

Department of Animal Science

University of California

Davis, California 95616

Carl G. Heller, M. D., Ph. D.

Director, Division of Reproductive Physiology

Pacific Northwest Research Foundation

1102 Columbia Street

Seattle, Washington 98104

Bryan Hudson, M。 D., Ph. D.

Professor of Medicine

Monash University

Prince Henry's Hospital

St. Kilda Road

Melbourne

Victoria 3004, Australia 
Jan E. Jirasek, M. D., D. Sc.

Assistant Professor of Obstetrics and Gynecology

University of Minnesota Medical School

Minneapolis, Minnesota 55455

Svend G. Johnsen, M。D。

Hormone Department

Statens Seruminstitut

Copenhagen S., Denmark

Professor Alfred Jost

Director, Laboratory of Comparative Physiology

Faculty of Sciences

9. quai Saint-Bernard

Paris 5e, 75 - France

Marian Jutisz, Ph. D.

Research Director in C.N.R.S.

Laboratoire de Physiologie Cellulaire

College de France

11 Place Marcelin Berthelot

75 - Paris V, France

Juan Carlos Lavieri, M. D.

Chief Laboratory of Andrology

Centro de Investigaciones Sobre Reproduccion

Facultad de Medicina

Paraguay $2155,10^{\circ} \mathrm{Piso}$

Buenos Aires, Argentina

Mortimer B. Lipsett, M. D.

Chief, Endocrinology Branch

National Cancer Institute

National Institutes of Health

Bethesda, Maryland 20014

Professor Bruno Lunenfeld, M. D.

Director, Institute of Endocrinology

Tel-Hashomer Government Hospital

Te1-Hashomer, Israe1

John MacLeod, Ph. D.

Professor of Anatomy

Cornell University Medical College

Department of Anatomy

1300 York Avenue

New York, New York 10021 
Professor Roberto E. Mancini, M。D.

Director

Centro de Investigaciones Sobre Reproduccion

Facultad de Medicina

Paraguay $2155,10^{\circ}$ Piso

Buenos Aires, Argentina

Professor Thaddeus Mann, M. D., Sc. D., Ph. D., F.R.S。

Professor of Physiology of Reproduction

Director, Unit of Reproductive Physiology and Biochemistry

University of Cambridge

Downing Street

Cambridge, England

Luciano Martini, M. D。

Professor of Pharmacology

Institute of Pharmacology

University of Milan

Via Vanvitelli, 32

20129 Milano, Italy

Anthony R. Means, Ph. D.

Assistant Professor

Vanderbilt University School of Medicine

Department of Obstetrics and Gynecology

Nashville, Tennessee 37203

Susumu Ohno, D.V.M•, Ph. D., D.Sc.

Chairman, Department of Biology

City of Hope Medical Center

1500 East Duarte Road

Duarte, California 91010

C. Alvin Paulsen, M. D.

Professor of Medicine

Chief, Division of Endocrinology

USPHS Hospital

University of Washington School of Medicine

P.0。Box 3145

Seattle, Washington 98114

Eugenia Rosemberg, M. D。

Research Director

Medical Research Institute of Worcester, Inc.

26 Queen Street

Worcester, Massachusetts 01610 
Griff T. Ross, M. D。, Ph. D.

Head, Endocrinology Service and

Assistant Chief, Endocrinology Branch

National Cancer Institute

National Institutes of Health

Building 10, Room 10B09

Bethesda, Maryland 20014

Professor Kenneth Savard, D. Sc.

Director, Endocrine Laboratory

University of Miami School of Medicine

Endocrine Laboratory

P.0. Box 875, Biscayne Annex

Miami, Florida 33152

Professor Carl Schirren, M。D。

Leiter der Andrologischen Abteilung

Universitatskrankenhaus Eppendorf

2 Hamburg 20, Martinistr. 52

Germany

Alberto J. Solari, M. D.

Centro de Investigaciones en Reproduccion

Facultad de Medicina

Paraguay 2155

Buenos Aires, Argentina

Anna Steinberger, $\mathrm{Ph}$. D.

Associate Member, Division of Endocrinology and Reproduction

Research Laboratories

Albert Einstein Medical Center

York and Tabor Roads

Philadelphia, Pennsylvania 19141

Emil Steinberger, M. D.

Chairman, Division of Endocrinology and Reproduction

Research Laboratories

Albert Einstein Medical Center

York and Tabor Roads

Philadelphia, Pennsylvania 19141

Philip Troen, M. D.

Physician-in-Chief

Montefiore Hospital

3459 Fifth Avenue

Pittsburgh, Pennsylvania 15213 
Oscar Vilar, M。D。

Associate Professor

Centro de Investigaciones en Reproduccion

Facultad de Medicina, $10^{\circ}$ Piso

Paraguay 2155

Buenos Aires, Argentina

J.-P. Weniger

Docteur de l'Universite de Strasbourg

Maitre de Recherche au Centre National de la Recherche Scientifique Universite de Strasbourg

rue de 1 'Universite, No. 12

67 Strasbourg, France

Emil Witschi, M. D., Ph. D.

The Population Council

Bio-Medical Division

The Rockefeller University

York Avenue and 66th Street

New York, New York 10021 
CONTENTS

\author{
CHAPTER I \\ EMBRYOLOGY OF THE MALE REPRODUCTIVE TRACT
}

Embryology of the Testis ................ 3

Emil Witschi

Hormonal Factors in the Development of the Male Genital System............ 11 Alfred Jost

The Relationship Between Differentiation of the Testicle, Genital Ducts and External Genitalia in Fetal and Postnatal Life........... . 19

Jan E. Jirasek

Heteroplastic Gonaduct-Testes Combinations: A Biochemical Outlook . . . . . . . 31 J. P. Weniger

Genera1 Discussion . . . . . . . . . . . . . . 39

CHAPTER II

HISTOLOGY OF THE TESTIS

Dynamics of Human Spermatogenesis . . . . . . . . . Yves Clermont

Electron Microscopy of the Human Seminiferous Tubules . . Oscar Vilar, C. Alvin Paulsen, and Donald J. Moore

Fine Structure of Testicular Interstitial Ce11s in Humans . 75 A. Kent Christensen 
Histology of the Human Testis from Neonatal Period to Adolescence . . . . . . . . . .

Oscar Vilar

\section{CHAPTER III}

CYTOGENETICS OF SPERMATOGENESIS

Morphological Aspects of Meiosis and Their Genetical

Susumu Ohno

Significance . . . . . . . . . .

U1trastructure and Histochemistry of the Nucleus During

Male Meiotic Prophase . . . . . . .

Alberto J. Solari and L. L. Tres

The Cytogenetics of the Male Germ Cells and the Testis

in Mammals .......... . . 139

C. E. Ford

Chromosome Studies on Testicular Cells of Subfertile Men.

Ann C. Chandley

CHAPTER IV

REGULATION OF TESTICULAR FUNCTION

SECTION 1: ROLE OF THE HYPOTHALAMUS

Mechanism of Action of FSH and LH Releasing Factors . . . 171

Irving I. Geschwind

Hypothalamic Control of Gonadotropin Secretion in

the Male.............. 187

L. Martini

Purification and Chemistry of Gonadotropin Releasing

Factors . . . . . . . .

Marian Jutisz

Further Studies on Mechanism of Action of Luteinizing Hormone Releasing Factor Using In Vivo

and In Vitro Techniques . . . . . . .

Marian Jutisz, Bernard Kerdelhue and Annette Berault 
Investigations Into the Feed-Back Mechanism Between Spermatogenesis and Gonadotropin Leve1 in Man .. . . . . . . . . . .

Svend G. Johnsen

The Role of FSH, ICSH, and Endogenous Testosterone During Testicular Suppression by Exogenous Testosterone in Norma1 Men . .

Car1 G. Heller, Howard C. Morse, Mike Su, and Mavis J. Rowley

SECTION 3: GONADOTROPINS, PURIFICATION AND MEASUREMENT

Use of Standards in Gonadotropin Assays . . . . . . . . . 263 Eugenia Rosemberg

Preparations and Biological Characteristics of HMG Piero Donini Preparations Used C1inica11y . . . . .

Plasma FSH and LH Measured by Radioimmunoassay in Griff T. Ross Normal and Pathologic Conditions in Men .

SECTION 4: METABOLIC EFFECTS OF GONADOTROPINS

Early Effects of FSH upon Testicular Metabolism . . . . . 301 Anthony R. Means

Radioautographic Studies of Protein Synthesis in Ce11s of the Seminiferous Epithelium..... Joseph R. Davis and Casimir F. Firlit

Studies of Spermatogenesis and Steroid Metabolism in

Cultures of Human Testicular Tissue . . .

A. Steinberger, M. Ficher and E. Steinberger 
SECTION 5: INFLUENCE OF GONADOTROPINS ON

TESTICULAR FUNCTION

Effect of Gonadotropins on the Seminiferous Tubules of

the Immature Testis . . . . . . . .

M. Courot

U1trastructura1 and Chemica1 Effects of LH upon the

Seminiferous Tubule ..........

Mario H. Burgos, F. L. Sacerdote, R. Vitale-Calpe, and D. Bari

Biologic Effect of Human Pituitary Luteinizing Hormone and Human Chorionic Gonadotropin . . .

E. Rosemberg, J. F. Crigler, Jr., W. F. Jan,

G. Bulat, R. Nakano, and S. G. Lee

The Effect of Gonadotropins on the Prepubertal Testis . . Cesar Bergada

\section{CHAPTER V}

\section{TESTICULAR STEROIDOGENESIS}

Steroid Secretion by the Human Testis . . . . . . . .

Mortimer B. Lipsett

Testosterone Plasma Levels in Normal and Pathological

Conditions . . . . . . . . . .

Bryan Hudson, H. G. Burger, D. M. de Kretser,

J. P. Coghlan, and H. P. Taft

Relation of In Vitro Metabolism of Steroids in

Human Testicular Tissue to

Histologic and Clinical Findings.....

E. Steinberger, M. Ficher, and K. D. Smith

Subcellular Structure and Synthesis of Steroids in

Kenneth Savard

the Testis.......... 459 


\section{CHAPTER VI}

NON-HORMONAL FACTORS INFLUENCING

SPERM PRODUCTION AND TRANSPORT

The Biochemical Characteristics of Spermatozoa and

Seminal Plasma .......... 469

Thaddeus Mann

The Significance of Deviations in Human Sperm Morphology . 481

John MacLeod

Pharmacological Studies on the Testicular Capsule in Relation to Sperm Transport .......

Joseph R. Davis and George A. Langford

Effect of Gonadotropins and Androgens on Fructose and

Citric Acid of Seminal Fluid . . . . . .

Juan Carlos Lavieri and Juan C. Calamera

Immunological Aspects of Male Infertility . . . . . .

Roberto E. Mancini

CHAPTER VII

GONADOTROPIN THERAPY

SECTION 1: TREATMENT OF HYPOPITUITARISM

Effects of HCG, HMG, HLH, and HGH Administration on

Testicular Function ......... 547

C. Alvin Paulsen, Duane H. Espeland, and

Edward L. Michals

Effect of Urinary FSH and LH on the Testicular Function

Roberto E. Mancini

in Hypogonadal Patients . . . . . . 563

The Effects of Urinary Gonadotropins Following

Hypophysectomy and in Hypogonadotropic

Eunuchoidism . . . . . . . . .

John MacLeod 
SECTION 2: TREATMENT OF ADULT SEMINIFEROUS

TUBULAR FAILURE

Assessment of Gonadotropin Therapy in Infertile Males . .

591

P. Troen, T. Yanaihara, H. Nankin, T. Tominaga,

and $\mathrm{H}$. Lever

Assessment of Gonadotropin Therapy in Male Infertility . .

Carl Schirren and Joseph 0. Toyosi

Assessment of Gonadotropin Therapy in Male Infertility . .

$B$. Lunenfeld and R. Shalkovsky-Weissenberg

General Discussion . . . . . . . . . . 631

Concluding Remarks . . . . . . . . . . . . 637

Eugenia Rosemberg and $C$. Alvin Paulsen

Index . . . . . . . . . . . . . 639 